ISSN 2694-5614

\title{
Antioxidant and Radical Scavenging of Piliostigma reticulatum using FRAP and DPPH
}

Daniel A. $\mathrm{O}^{1^{*}}$ and Taye Temikotan ${ }^{2}$

${ }^{1}$ Department of Biological Sciences, Achievers University, Owo, Ondo State

${ }^{2}$ Department of Biological Sciences, Achievers University, Owo, Ondo State

\author{
*Correspondence author \\ Daniel A. O \\ Department of Biological Sciences \\ Achievers University \\ Owo \\ Ondo State
}

Submitted : 1 Feb 2020 ; Published : 6 Apr 2021

\begin{abstract}
The antibacterial activity, phytochemical constituents and the radical scavenging ability using FRAP and DPPH of Piliostigma reticulatum were investigated in this study. Of all the solvent extracts used to assay the antibacterial effect, ethanol extract had the highest activity, followed by the aqueous extract with very weak activity against Pseudomonsa aeruginosa, Salmonella typhi and E. coli, methanol extract had no visible effect on the test organisms while ethyl acetate was active against only E. coli. The presence of phytochemicals such as alkaloids, glycosides, steroids, anthraquinones, phenol, tanin and saponin was observed. Antinutrients such as Tanin, Phenol, Phylate, Oxalate, Saponin and Flavonoids in copious amount. Ethanol extract of P. reticulatum was found to have the highest antioxidant ability, followed by the methanol extract. Ehtyl acetate extract had minimal radical scavenging ability. The antibacterial effect, phytochemical content and the radical scavenging properties of the plant makes it a good candidate in the development of antimicrobial therapeutics.
\end{abstract}

Keywords: Antioxidant; Radical Scavenging; Antibacterial; Antinutrients

\section{Introduction}

Reactive oxygen species are produced in the human body as a result of metabolism, food consumed by humans and overproduction and imbalance of free radicals as result of oxidative stress. Overproduction of free oxygen radicals lead to aging, cellular injury chronic diseases such as cardio-vascular, cerebrospinal diseases and death [1]. Researchers are on the lookout for compounds with high antioxidant activities in order to use them in foods and pharmaceutical preparations to replace the synthetic ones [2]. Plants have a large number of bioactive compounds with high natural antioxidant activity with little or no side effects.

Medicinal plants are the major source of chemical compounds exhibiting antioxidant activity. Several studies have reported the amazing composition of medicinal plants, including phenolic acids, flavonoids, and tannins, which are known for their health benefits as antioxidants [3]. The aim of this work is to estimate the antioxidant and radical scavenging abilities of Piliostigma reticulatum using known methods; The FRAP (Ferric reducing ability of plasma) and DPPH (1,1,Diphenyl-2-2picrylhydazyl) assays. The FRAP assay evaluates the total antioxidant power and it is chosen to estimate the presumable effects of the medicinal plants used in this study. FRAP assay depend on the ferric tripyridyltriazine (Fe(iii)TPTZ complex to the ferrous tripyridytriazine (Fe(ii)TPTZ) by a reductant at low $\mathrm{pH}$. DPPH is a well-known radical trap for other radicals.

Piliostigma reticulatum is a plant that occurs in the SaheloSudanian region of Africa from Senegal, Mauritania to Sudan. The plant is a dioeciously shrub or small tree up to 10-15 meters tall, bole short, rarely straight, up to $30 \mathrm{~cm}$ in diameter. The outer bark is deeply fissured, cracked grey to brown, and the inner bark pink to red crown rounded and dense. The branches are grey, waxy, and glabrous. The leaves alternate conspicuously bilobed, petiole 1-3.5 cm long, swollen at both ends, blade 5-12 cm X 4-18 cm, chordate or rounded at base, lobes rounded more or less cuneate. The flowers are unisexual, $2.5 \mathrm{~cm}$ in diameter, calyx 5 toothed, 15-20 cm long, petals 5 obovate, white with pink stripes, male flowers with 10 stamens, anthers brown. Fruit an oblong pod $15-30 \mathrm{~cm}$ X $2.5-5 \mathrm{~cm}$, straight undulate woody, hard, glabrous, or sparsely pubescent, brown flat, pruinose, sometimes twisted and cracked, indehiscent and persisting, many seeded [4].

The plant is used widely in Africa as a traditional medicine for the treatment of many diseases, such as malaria, tuberculosis, and diarrhea [5]. Piliostigma reticulatum is used in traditional medicine in Cameroon to treat epilepsy, anxiety, and agitation. In fact the results of a study done in Cameroon suggested that it possesses anxiolytic and antipyretic properties in mice and could 
really be helpful in the treatment of anxiety [6].

\section{Methods and Materials}

Plant preparation and extraction

Stem bark of Piliostigma reticulatum was purchased from a traditional herb seller at Ibode, Ibadan, Oyo Stae, Nigeria. The plant was identified by Mr F. O. Omotayo of the Department of Plant Science and Biotechnology, Ekiti State University, Ado Ekiti. Voucher specimen was deposited at the herbarium of the department.

The plant sample was air dried for several weeks and the moisture content was determined. The dried stem was pounded first with mortar and pestle and then pulverized to smooth powder using the electric blender. The prepared sample was kept in clean container until use.

\section{Extraction procedure}

$250 \mathrm{gm}$ of plant powder was suspended in $500 \mathrm{ml}$ of distilled water, ethanol, methanol and ethyl acetate and the solutions were allowed to stand under room temperature with constant agitation using the magnetic stirrer for $120 \mathrm{hr}$ after which the solutions were filtered using Whatsman no 1 filter paper as described by Fabricanth and Farnsworth (2001) [7]. The filtrates were evaporated to dryness using the rotary evaporator and the crude extracted were reconstituted with 50\% DMSO.

\section{Sterilization of crude extract}

The crude extract was sterilized by passing through Millipore membrane filter with pore size $0.45 \mu \mathrm{m}$. The filtrates were then stored in sterile bottles until use.

\section{Collection and maintenance of microorganisms}

The test bacteria (Pseudomoas aeruginosa, Staphylococcus aureus and Salmonella typhi) and fungi were obtained from the Department of Microbiology, Obafemi Awolowo University, Ileife, Osun State. The organisms were collected and maintained by regular subculturing on nutrient and potato dextrose agar slants respectively. The test organisms were subjected to biochemical test to confirm the authenticity of the organisms.

\section{Standardization of inocula}

One percent (1\%) of solution of sulphuric acid was prepared and mixed properly. Also, $1 \%$ solution of Barium chloride was prepared by dissolving $0.5 \mathrm{~g}$ of dehydrated barium chloride $(\mathrm{BaCl} 2 . \mathrm{H} 2 \mathrm{O})$ in $50 \mathrm{ml}$ of distilled water. A $0.5 \mathrm{ml}$ aliquot of barium chloride solution was added to $99.5 \mathrm{ml}$ of the sulphuric acid solution and it was the mixed together. The solution was transferred into a capped tube of the same type used for both the control and the test inocula. The solution was kept at room temperature of $+4 \mathrm{OC}$ [8].

\section{Sterilization of crude extracts}

A five gram portion of the crude extract were reconstituted in 50\% dimethyl sulfoxide, the solutions were sterilized by passing them through millipore membrane filter with pore size $0.45 \mu \mathrm{m}$. The filtrates were then stored in sterile bottles until use.

\section{Serial dilution of crude extracts}

A stock solution of $100 \mathrm{mg} / \mathrm{ml}$ of crude extract in dimethyl sulfoxide was subjected to dilution with distilled water to prepare $60 \mathrm{mg} / \mathrm{ml}, 40 \mathrm{mg} / \mathrm{ml}, 20 \mathrm{mg} / \mathrm{ml}, 10 \mathrm{mg} / \mathrm{ml}$ concentrations.
Antibacterial assay of the plant extracts using the agar well diffusion method

Test organisms were suspended in nutrient broth and incubated for 4 hours to obtain a concentration corresponding to McFarlands constant $(0.5 \times 108 \mathrm{cfu} / \mathrm{ml})$. The inoculum was standardized with the prepared barium sulphate as described in 3:7. Sterile petri dishes were inoculated by the pour plate method. One $\mathrm{ml}(1 \mathrm{ml})$ of the test inoculum was pipetted aseptically into each petri dish and about $20 \mathrm{ml}$ of sterilized nutrient agar was poured into the inoculated petri dish.

The agar plates were allowed to set wells of $6 \mathrm{~mm}$ diameter were made over the agar plates equidistant from each other using sterile cork borer and $0.5 \mathrm{ml}$ of each plant extracts of different concentrations as prepared by the serial dilution were added to the wells using a micropipette. The extracts were allowed to diffuse into the agar for about 20 minutes after which the plates were incubated for $24 \mathrm{~h}$ at $37 \mathrm{oC}$. Thereafter, the diameter of inhibition zones formed around each well was measured in $\mathrm{mm}$ and recorded. The experiments were carried out in triplicates and the average values recorded.

\section{Determination of minimum inhibitory concentration (MIC) of plant extracts against test organisms}

A modified method of Weigand et al. (2008) was adopted in the determination of MIC [9]. The MIC of the extracts was determined by diluting the various concentrations with nutrient broth. A $1 \mathrm{ml}$ aliquot of a serial dilution of $100 \mathrm{mg} / \mathrm{ml}, 60 \mathrm{mg} / \mathrm{ml}, 40 \mathrm{mg} / \mathrm{ml}$, $20 \mathrm{mg} / \mathrm{ml}$ and $10 \mathrm{mg} / \mathrm{ml}$ of the extracts was separately added to test tubes containing specifically $0.1 \mathrm{ml}$ of standardized inoculum of 1 to $2 \times 107 \mathrm{cfu} / \mathrm{m}$. The tubes were incubated aerobically at $37 \mathrm{oC}$ for $18-24 \mathrm{hrs}$. Two control tubes were prepared for each test batch. This is as follows: tube containing extracts and the growth medium without inoculums (antibiotic control) and the tube containing the growth medium and the inoculums (organism control). The inocula were then plated and inoculated at $37 \mathrm{oC}$ for $24 \mathrm{hrs}$. The MIC was determined as the lowest concentration of the extracts exhibiting no visible growth (no turbidity) when compared with the control tubes.

\section{Determination of antibiotics sensitivity}

Gram-positive and Gram-negative susceptibility testing using standard antibiotics; Gentamycin $(10 \mu \mathrm{g})$, and Chloramphenicol $(10 \mu \mathrm{g})$ were carried out using the disk diffusion method of KirbyBauer et al. (1966) [10]. Nutrient agar plates were prepared and seeded with bacterial inoculum using the pour plate method. After gelling, antibiotic disk were placed on the gelled plate and the plates were incubated at $37 \mathrm{oC}$ for $24 \mathrm{hr}$ after which the zones of inhibition were observed and recorded.

\section{Phytochemical screening of plant materials}

Active plants were screened qualitatively for phytochemicals using the methods of Odebiyi and Sofowora (1993), Trease and Evans (2002) and Banso and Ngbede, (2006) [11, 12, 13].

\section{Test for alkaloids}

A $0.2 \mathrm{~g}$ amount of plant extract was acidified with $1 \%$ hydrochloric acid $(\mathrm{HCl})$ for $2 \mathrm{~min}$ and was then treated with a few drops of Dragendorff's reagent in a test tube. The formation of white precipitate indicates the presence of alkaloids. 
Test for saponins

Sterile distilled water was used to dissolve $0.2 \mathrm{~g}$ of plant extract. A $2 \mathrm{ml}$ amount of the solution was placed in different test tubes and was shaken vigorously for a few minutes. Frothing which persists on warming was taken as an evidence of the presence of saponin.

Test for tannims (Gelatin Test)

To the extract, $1 \%$ gelatin solution containing sodium chloride was added. Formation of white precipitate indicates the presence of tannins.

\section{Test for flavonoids (Shinoda's Tests)}

Plant extract was dissolved in $2 \mathrm{ml}$ of dilute $\mathrm{NaOH}$. A yellow solution that turns faint or colorless on addition of a few drops of hydrochloric acid and a change in colour while standing indicates the presence of flavonoids.

\section{Test for cardiac glycosides (Liberman's Test)}

The Liberman's test was used to determine the presence of cardiac glycosides. A $5 \mathrm{~g}$ amount of plant extract was dissolved in $20 \mathrm{ml}$ of acetic anhydride and cooled with ice. Concentrated H2SO4 was then carefully added. A colour change from violet to blue and then to green indicated the presence of a steroidal nucleus (a glycone portion of the cardiac glycoside).

\section{Test for steroids (Salkowski Test)}

A $0.5 \mathrm{~g}$ portion of plant extract was dissolved in $2 \mathrm{ml}$ of chloroform and $0.2 \mathrm{ml}$ of concentrated $\mathrm{H} 2 \mathrm{SO} 4$ was carefully added to form a layer. A reddish-brown colour ring at the interface between the layers indicated the deoxy- sugar characteristic of cadenolides which indicated the presence of steroids.

\section{Preparation of reagents for FRAP and DPPH assay Scavenging activity against 1,1-Diphenyl-2-Picryl Hydra- zyl Radical (DPPH)}

The crude extracts of different solvents (ethyl acetate, ethanol and methanol) of the plants were screened for DPPH radical Scavenging activity. DPPH radical scavenging activity was measured according to the method of Ayoola et al. (2006) [14].

Solution of the extracts were prepared by dissolving $1 \mathrm{~g}$ of dry extract in $10 \mathrm{ml}$ of methanol. An aliquot of $1 \mathrm{ml}$ of DPPH solution in methanol and $1 \mathrm{ml}$ of plant extract in methanol at various concentrations $(2 \mathrm{mg} / \mathrm{ml}, 4 \mathrm{mg} / \mathrm{ml}, 8 \mathrm{mg} / \mathrm{ml}$ and $10 \mathrm{mg} / \mathrm{ml})$ were mixed and incubated at $25^{\circ} \mathrm{C}$ for $30 \mathrm{~min}$ and absorbance of the test mixture was read at $517 \mathrm{~nm}$ using a spectrophotometer (T 70 UV-VIS Spectrometer, PG Instruments Ltd.) against a DPPH control containing only $1 \mathrm{ml}$ of methanol in place of the extract. The DPPH solution in methanol was prepared daily before the absorbance measurements. DPPH is a purple coloured stable free radical. When reduced it gives the yellow coloured Diphenyl picryl hydrazine. The free radical scavenging activity of each fraction was determined by comparing its absorbance with that of a blank solution (no sample). All experiments were performed thrice and the results were averaged. Percent inhibition was calculated using the following expression:

$\%$ Inhibition $=$

\section{(1-(A DPPH+sample - A sample + distilled water) ) X 100} $\mathrm{DPPH}$
The values of the extracts scavenging abilities were plotted and recorded.

\section{Evaluation of the total antioxidant ability using FRAP assay}

The determination of the total antioxidant activity (FRAP assay) in the extract is a modified method of Benzie and Strain [15]. The stock solutions included $300 \mathrm{mM}$ acetate buffer (3.1 $\mathrm{g} \mathrm{C}_{2} \mathrm{H}_{3} \mathrm{NaO}_{2} \cdot 3 \mathrm{H}_{2} \mathrm{O}$ and $16 \mathrm{ml} \mathrm{C}_{2} \mathrm{H}_{4} \mathrm{O}_{2}$ ), pH 3.6, $10 \mathrm{mM} \mathrm{TPTZ}$ (2, 4, 6-tripyridyl-s-triazine) solution in $40 \mathrm{mM} \mathrm{HCl}$, and $20 \mathrm{mM}$ $\mathrm{FeCl}_{3} \cdot 6 \mathrm{H}_{2} \mathrm{O}$ solution. The fresh working solution was prepared by mixing $25 \mathrm{ml}$ acetate buffer, $2.5 \mathrm{ml} \mathrm{TPTZ}$, and $2.5 \mathrm{ml} \mathrm{FeCl}_{3} \cdot 6 \mathrm{H}_{2} \mathrm{O}$. The temperature of the solution was raised to $37^{\circ} \mathrm{C}$ before use. Plant extracts $(150 \mu \mathrm{L})$ were allowed to react with $2850 \mu$ l of the FRAP solution for $30 \mathrm{~min}$ in the dark condition. Readings of the colored product (ferrous tripyridyltriazine complex) were taken at $593 \mathrm{~nm}$. Results are expressed in M Fe (II)/g dry mass and compared with that of ascorbic acid.

\section{Results and Discussion}

\section{Antibacterial activity of plant extracts}

From the test result presented in table 1, The aqueous extract of the plants was less active than the other solvent extracts with the zone of inhibition of $11 \mathrm{~mm}$ against Pseudomonas aeruginosa at $100 \mathrm{mg} / \mathrm{ml}$ and $10 \mathrm{~mm}$ at $60 \mathrm{mg} / \mathrm{ml}$. Similarly, a zone of inhibition of $10 \mathrm{~mm}$ was recorded against Salmonella typhi at $100 \mathrm{mg} / \mathrm{ml}$ while $12 \mathrm{~mm}$ was recorded against $E$. coli at $100 \mathrm{mg} / \mathrm{ml}$ of extract. On the other hand, the ethanol extract of P. reticulatum was active against the test organisms with zones of inhibition ranging from $16 \mathrm{~mm}$ at $100 \mathrm{mg} / \mathrm{ml}$ to $10 \mathrm{~mm}$ at $40 \mathrm{mg} / \mathrm{ml}$ against $E$. coli, $18 \mathrm{~mm}$ at $100 \mathrm{mg} / \mathrm{ml}$ to $12 \mathrm{~mm}$ at $40 \mathrm{mg} / \mathrm{ml}$ against Pseudomonas aeruginosa and $16 \mathrm{~mm}$ at $100 \mathrm{mg} / \mathrm{ml}$ to $12 \mathrm{~mm}$ at $40 \mathrm{mg} / \mathrm{ml}$ against Salmonella typhi. Interestingly, the methanol extract of the plant did not show any activity against all the test organisms. This observation is contrary to the work of Zerbo et al (2010) who recorded activity against E. coli, Salmonella typhimorium and other bacteria, although the study was carried out using the broth dilution method [16]. This discrepancy in result could be because of the diffusion ability of the extract through solid medium, although in the same study, the decoction of the extract was observed to have higher antibacterial activity that the methanol extract.

On the other hand, Awe and Omojasola (2009) observed a similar result to this study where a better antibacterial activity was recorded for the ethanolic extract of $\mathrm{P}$. reticulatum compared to the aqueous extract [17]. This observation may not be far from the extraction ability of ethanol because of its polarity. The ethyl acetate extract has the highest antibacterial activity as compared to the ethanol extract against E. coli but showed no activity against Pseudomonas aeruginosa and Salmonella typhi. This is an interesting development as all three test organisms are Gram negative and Gram negative bacteria are known to be highly resistant to quite an array of antimicrobial agents because of the nature of their cell wall composition which is multilayered and complex [18]. The selective susceptibility of E. coli cannot therefore be readily explained and this could be further investigated, however, according to Prescott, (2002) effect of antimicrobial agent varies with the target specie. 


\begin{tabular}{|c|c|c|c|c|c|c|c|c|c|c|c|c|c|c|c|c|c|c|c|c|c|c|}
\hline \multicolumn{23}{|c|}{ Zones of Inhibition in $\mathrm{mm}$} \\
\hline & \multicolumn{5}{|c|}{ Aqueous } & \multicolumn{5}{|c|}{ Ethanol } & \multicolumn{5}{|c|}{ Methanol } & \multicolumn{5}{|c|}{ Ethyl acetate } & \multirow[t]{2}{*}{ Chl } & \multirow[t]{2}{*}{ Gen } \\
\hline 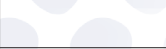 & 100 & 60 & 40 & 20 & 10 & 100 & 60 & 40 & 20 & 10 & 100 & 60 & 40 & 20 & 10 & 100 & 60 & 40 & 20 & 10 & & \\
\hline E.coli & 12 & 1 & - & - & - & 16 & 12 & 10 & - & - & - & - & - & - & - & 22 & 20 & 18 & - & - & 24 & 20 \\
\hline $\begin{array}{l}P . \\
\text { aeruginosa }\end{array}$ & 11 & 10 & - & - & - & 18 & 16 & 12 & - & - & - & - & - & - & - & - & - & - & - & - & - & 12 \\
\hline S. typhi & 10 & - & - & - & - & 16 & 14 & 12 & - & - & - & - & - & - & - & - & - & - & - & - & - & - \\
\hline
\end{tabular}

Chl : chloraphenicol; Gen : Gentamycin

Table 1: Antibacterial activity of plant extract.

Comparative antibiotic screening against the test organisms shows that chloramphenicol and gentamycin were effective against $E$.coli while only gentamycin was active against $P$. aeruginosa. On the contrary, $S$. typh $i$ was resistant to both chloramphenicol and gentamycin. Several authors have observed the high level of resistance of these organisms to several antibiotics [19, 20].

Phytochemical constituents of plants

Plants have been known to contain large variety of bioactive materials that are responsible for their antimicrobial and antioxidant properties can be attributed to the phytochemicals present in them.

Qualitative phytochemical screening of plant has revealed the presence of numerous chemicals including alkaloids, tannins, flavonoids, steroids, glycosides, saponins (Table 2).

\begin{tabular}{|l|l|l|l|l|l|l|}
\hline Plant & Tanin & Phenol & Phylate & Oxalate & Saponin & Flavonoids \\
\hline P. reticulatum & 2.32 & 2.50 & 15.65 & 6.57 & 9.71 & 6.49 \\
\hline
\end{tabular}

Table 2: Phytochemical content of $P$. reticulatum.

These phytochemicals are responsible for the biological activities of this plant. This result correlates with the findings of Adeyanju et al., (2010), Musa et al., (2008) and Ojewale et al., (2013) [21, 22, 23]. Phenolic compounds and flavonoids have also been reported to be associated with anti-oxidative action in biological systems, acting as scavengers of singlet oxygen and free radicals (Maquid, 2017). Consequently, the presence of these phytochemicals makes the plant to be a potential source of crude drug that can positively serve as a model for modern drugs. This view was supported by Ahmadian, (2000) [24], who reported that tanins and/ flavonoids of medicinal origin were found to possess significant pharmacological activities: antidiarroehal, analgesic, and anti-inflammatory amongst others in the animal body system. plant also contains considerable amount of antinutrients as presented in table 3 . Antinutrients such as phylate (15.65), saponin (9.71), flavonoids (6.49) oxalate (6.57), phenol (2.50) and tanin (2.32). However, antinutrients found in these plants are natural substances that interfere with the absorption of nutrients (Oxford Dict, 2006). Phytic acids has strong binding affinity to minerals such as calcium, copper, magnesium, iron and zinc [25]. Excessive intake of required nutrients can result in them having antinutrient action [26].

\begin{tabular}{|l|l|l|l|l|l|l|l|}
\hline Plant & Alkaloids & Glycosides & Steroids & Anthraquinones & Phenol & Tanin & Saponin \\
\hline P. reticulatum & +ve & +ve & +ve & ND & +ve & +ve & +ve \\
\hline
\end{tabular}

$+\mathrm{ve}:$ Present; ND : Not Discovered

Table 3: Antinutrients present in P. reticulatum.

Radical scavenging ability of plant using DPPH

Oxidative stress has been linked to many age related diseases such as diabetes, arthritis, cardiovascular, atherosclerosis and neurodegenerative diseases among others (Parkinson, Alzheimer, and Huntington), cancer, and aging [27, 28, 29]. Antioxidants from plants such as phenolic acids and flavonoid compounds offer protection against the oxidative stress and related diseases by scavenging free radicals, inhibiting lipid peroxidation, and by other mechanisms [30, 31].

The ethanol and methanol extracts of the plants have the highest scavenging ability. The ethanol extract reduced the total free radicals from $80 \%$ to $40 \%$ and methanol reduced the free radicals from $80 \%$ to about $45 \%$. While the ethyl acetate extract was able to scavenge the free radicals to about $60 \%$ (Fig. 1). Interestingly, Ethyl acetate extract has the highest antibacterial activity while methanol had no effect on the bacterial strains used (Table 1). The scavenging ability of this plant could be as a result of the presence of phytochemicals such as phenol, amino acids and the alkaloids present in the plant. 


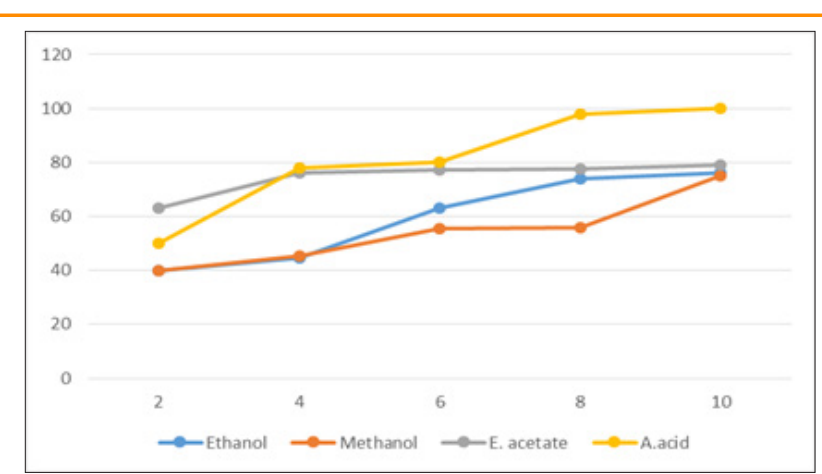

Figure 1: The radical scavenging ability of the ethanol, methanol and ethyl acetate extracts of Piliostiogma reticulatum.

Manthey, J.A (2011); Bandoniene and Murkovic (2002) in their work attributed the radical scavenging abilities of plants to the presence of phenolic compounds [32, 33]. Pietta (2000) opined that the antioxidant activities of plants is predominantly as a result of their redox potentials which makes them act as reducing agents, hydrogen donor and singlet oxygen quenchers [34]. Zerbo et al., (2010) also discovered in their work that the methanolic extract of the stem bark of Piliostigma reticulatum was able to scavenge free radicals [16].

\section{Radical scavenging ability of plant using FRAP}

The FRAP assay measures the reducing potentials of an antioxidant reacting with a ferric tripyrdyltriazine ( $\left.\mathrm{Fe}^{3+}-\mathrm{TPTZ}\right)$ complex to produce colored ferrous tripyridyltriazine $\left(\mathrm{Fe}^{2+}-\right.$ TPTZ). $P$. reticulatum was able to scavenge free radical to a certain extent. The FRAP values of this plant varied from 0.15 to 0.24 depending on the extraction solvent. Methanol extract had the higher scavenging ability of 0.17 , followed by the ethanolic extract with 0.15 and ethyl acetate with 0.25 whereas the value of ascorbic acid was 0.02 (Fig 2). On weigh to weight basis us, the result of the two radical scavenging procedures although with different methodologies as certain the fact that $P$. reticulatum has the oxidation ability to an extent. This results corroborates the result of the phytochemical content of the plant which showed the phenol content to below (Table 2).

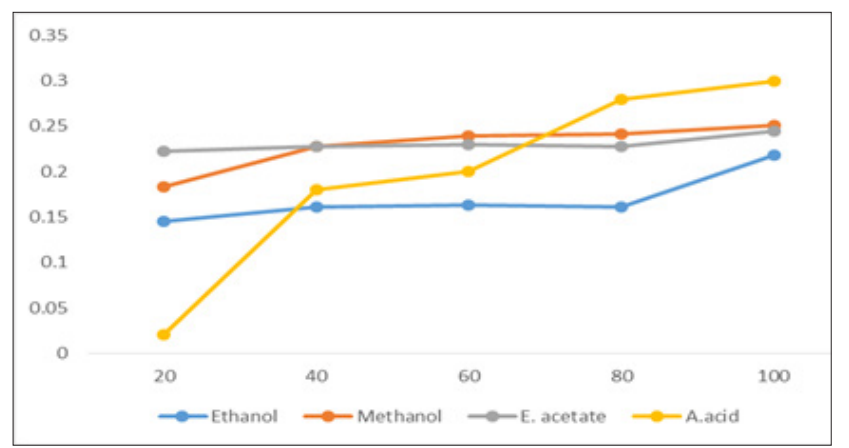

Figure 2: Radical scavenging ability of Piliostigma reticulatum using FRAP

The FRAP values of some medicinal plants range from 0.3 and $120 \mathrm{mmol} / \mathrm{g}$. The values obtained in the FRAP analysis of $P$. reticulatum are lower than the range reported by Dragland et al., (2003) [35], but it is still higher than the FRAP values of black tea $(0.8 \mathrm{mmol} / \mathrm{g})$ and comparable to green tea $(2.5 \mathrm{mmol} / \mathrm{g})$
[36].

The synergistic effects of the phytochemicals present in the plant could be responsible for the antioxidant activities. The FRAP assay was used by several authors for the assessment of antioxidant activity of various food product samples suggested that most of the secondary metabolites are redox-active compounds that will be picked up by the FRAP assay $[37,38]$.

\section{Conclusion}

The present study provides information about the phytochemical content, proximate composition, antibacterial activity and the oxidative capacity of Piliostigma reticulatum, a plant used for therapeutic and folkloric purposes. The low phenolic content of the plant could be responsible for the low scavenging ability of the plant, however, it is a good candidate as an antibacterial agent which can be used in combination with other natural antioxidant to maximize the activity of the plant.

\section{References}

1. Wong S P, Leong L P, and Koh J H (2005). Antioxidant activities of aqueous extracts of selected plants. Journal of Food chemistry, 99(4), 775-783.

2. Halliwell B, Guttridge J M and Cross (1992). Free radicals, antioxidants and human disease, Where are we now? Journal of Laboratory and Clinical Medicine, 119(6), 598-620.

3. Jemli M E, Rabie Kamal R, Ilias Marmouzi I, Asmae Zerrouki A, Yahia Cherrah Y, and Katim Alaoui K (2016). Radical-scavenging activity and ferric reducing ability of Juniperus thurifera (L.), J. oxycedrus (L.), J. phoenicea (L.) and Tetraclinis articulata (L.). Advances in Pharmacological and Pharmaceutical Sciences, 2016. doi: https://doi.org/10.1155/2016/6392656

4. Keay R W J (1989). Trees of Nigeria. Oxford, UK; Clarendon.

5. Dosso K, N'guessan B B, Bidie A P, Gnangoran B N, Méité S, N'guessan D, Yapo A P, E E Ehilé (2012). Antidiarrhoeal activity of an ethanol extract of the stem bark of Piliostigma reticulatum (Caesalpiniaceae) in Rats. African Journal of Traditional, Complementary, and Alternative Medicines, 9(2), 242-249.

6. Sidiki N (2013). Anxiolytic and antipyretic activities in the decoction of leaves of Piliostigma reticulatum. Asian Journal of Pharmaceutical and Health Sciences (AJPHS), 3(1), 654-660.

7. Fabricant D S and Farnsworth N R (2001). The value of plants used in traditional medicine for drug discovery. Environmental Health Perspectives, 109(Suppl 1), 69-75.

8. Cheesbrough M (2000). Microbiological test. District Laboratory Practice in Tropical countries pp 1-226.

9. Weigand I, Hilpert K, Robrert E and Hancock W (2008). Agar broth dilution methods to determine the minimal inhibitory concentration (MIC) of antimicrobial 
substances. Natural Protocols, 3(2), 163-175.

10. Bauer A W, Kirby W M W, Sherris J C and Turck M (1966). Antibiotic susceptibility test by a standardized single disk method. American Journal of Clinical Pathology, 45(4), 493-496.

11. Odebiyi O O and Sofowora E A (1978). Phytochemical screening of Nigerian medicinal plants II, Lloydia, 41(3), 234-46.

12. Trease G E, and Evans W C (2002). Pharmacognosy. $15^{\text {th }}$ ed. London Publishers. pp 42-44, 221-229, 246-249, 304306.

13. Banso A and J E Ngbede (2006). Phytochemical screening and in vitro antifungal properties of Fagara zanthoxyloides. Journal of Food Agriculture and Environment, 4(3), 8-9.

14. Ayoola G A, Sofidiya T, Odukoya O, Coker H A B (2006). Phytochemical screening and free radical scavenging activity of some Nigerian medicinal plants. Journal of Pharmaceutical Sciences \& Pharmacy Practice, 8, 133136.

15. Okudu T, Yoshida T, Hatano T(1994). Food phytochemicals for cancer prevention II. In Ho C. T, Osawa T, Huang MT, Rosen R.T. Chemistry and antioxidative effects of phenolic compounds from licorice, tea and Compositae and Labiateae herbs : Washington, DC: American Chemical Society, 132-143.

16. Zerbo A, Koudou J, Ouédraogo N, Ouédraogo R and Guissou I P (2010). Antioxidant and antibacterial activities of Piliostigma reticulatum (DC.) Hochst extracts. African Journal of Biotechnology, 9(33), 5407-5411.

17. Awe S and Omojasola P F (2009). A comparative study of the antibacterial activity of Piliostigma reticulatum bark extract with some antibiotics. Ethnobotanical leaflets, 13, 1197-1204.

18. Essawi T and Strour M (2000). Screening of some Palestinian medicinal plants for antibacterial activity. Journal of Ethnopharmacology, 70(3), 343-349.

19. Abdulahi M, Esaya T, and Hailu D (2013). Seroprevalence of bovine foot and mouth disease (FMD) in Awbere and Babille districts of Jijiwa zone. Somalia Regional State, Eastern Ethiopia. African Journal of Microbiology Research, 5(21), 3559-3563.

20. Hatha M,AA Vivekanandham, G Joice J, G Christol (2005). Antibitoicc resistance pattern of motile aeromonads from farm raised fresh water fish. International Journal of Food Microbiology, 98(2), 131-134.

21. Adeyanju $\mathrm{O}$, Olajide $\mathrm{O} \mathrm{O}$, Afolayan $\mathrm{M}$ and Arifalo $\mathrm{K}$ M (2010). Preliminary phytochemical and antimicrobial screening of the leaf extracts of Piliostigma reticulatum. African Journal of Pure and Applied Chemistry, 5(3), 4346.

22. Musa N, Wei S L, Shaharom F and Wee W (2008).
Surveillance of bacteria specie in diseased freshwater ornamental fish from aquarim workshop. World Applied Sciences Journal, 3, 903-905.

23. Ojewale A O, Adekoya A O, Odukanmi A, Olaniyan O T, Ogunmodede O S and Dare B J (2013). Protective effect of ethanolic root extract of Pseudocedrella kotchyii (pk) on some hematological and biochemical parameters in alloxan-induced diabetic rat. World Journal of Pharmacy and Pharmaceutical Sciences, 2(3), 852-866.

24. Ahmadiani R N, Navaro D S, Semnaniian S, Javan M, Saeed F, M Kamalinejad and Saremi S (2000). Antinoceptive and antiinflammatory effects of Elaeagnus angustifolia fruit extract. Jounrnal of Ethnophamacology, 72(1-2), 287-292.

25. Ekholm P, Virkki L, Ylinen M and Johansson L (2003). The effect of phytic acid and some natural chelating agents on the solubility of mineral elements in oat bran. Food Chemistry 80(2), 165-167.

26. Golam-Masum-Akond A S M, L Khandaker, J Berthold, L Gates, K Peters, H Delong and K Hossain (2011). Anthocyanin, total olyphenols and antioxidant activity of common bean. American Journal of Food Technology, 6, 385-394.

27. Hybertson B M, Gao B, Bose S K and McCord J M (2011). Oxidative stress in health and disease: The therapeutic potential of Nrf2 activation. Molecular Aspects of Medicine, 32(4-6), 234-246.

28. Liang D, Zhou Q, Gong W, et al., (2011). Studies on the antioxidant and hepatoprotective activities of polysaccharides from Talinum triangulare. Journal of Ethno-pharmacology, 136(2), 316-321.

29. Rains J L and Jain S K (2011). Oxidative stress, insulin signaling, and diabetes. Free Radical Biology and Medicine, 50(5), 567-575.

30. Masella R, Di Benedetto R, Varì R, Filesi C and Giovannini C (2005). Novel mechanisms of natural antioxidant compounds in biological systems: involvement of glutathione and glutathione-related enzymes. Journal of Nutritional Biochemistry, 16(10), 577-586.

31. Dai J and Mumper R J (2010). Plant phenolics: Extraction, analysis and their antioxidant and anticancer properties. Molecules, 15(10), 7313-7352.

32. Manthey J A (2011). Biological properties of flavonoids pertaining to inflammation. Microcirculation, 7(6 Pt 2), S29-34.

33. Bandoniene D and Murkovic M (2002). The detection of radical scavenging compounds in crude extract of borage (Borago officinalis L.) by using an on-line HPLC-DPPH method. Journal of Biochemical and Biophysical Methods, 53(1-3), 45-49.

34. Pietta P G (2000). Flavonoids as antioxidants. Journal of 
Natural Products, 63(7), 1035-1042.

35. Dragland S, Senoo H, Wake K, Holte K, Blomhoff R (2003). Several culinary and medicinal herbs are important sources of dietary antioxidants. Journal of Nutrition, 133(5), 1286-1290.

36. Blomhoff R (2005). Dietary antioxidants and cardiovascular disease. Current Opinions in Lipidol., 16(1), 47-54.

37. Halvorsen B L, Carlsen M H, Phillips K M, Bohn S K, Holte k, Jacobs Jr D R, Blomhoff R (2006). Content of redox-active compounds (i.e antioxidant) in foods consumed in the United States. American Journal Clinical Nutrition, 84(1), 95-135.

38. Pelligrini N, Serafini M, Colombi B, Rio D D, Salvatore S, Bianchi M, Brighenti F (2003). Total antioxidant capacity of plant foods, beverage and oils consumed in Italy assessed by three different in vitro assays. Journal of Nutrition, 133(9), 2812-2819.

Copyright: ${ }^{0} 2021$ Daniel A. O. This is an open-access article distributed under the terms of the Creative Commons Attribution License, which permits unrestricted use, distribution, and reproduction in anymedium, provided the original author and source are credited. 